\title{
The most probable Eumetazoa among late Precambrian macrofossils
}

\author{
A.Yu. Ivantsov \\ A.A. Borissiak Paleontological Institute of RAS, Profsoyuznaya st., 123, Moscow, 117647, Russia. \\ E-mail: ivancov@paleo.ru
}

ABSTRACT: In late Precambrian macrofossil assemblages ascribed to shallow-water marine benthos, remains of colonial bacteria, multicellular algae, giant protozoans, parazoans, and eumetazoans of various phyla were provisionally identified. However, the reliability of these definitions is vanishing due to limitations imposed by a specific preservation of Precambrian fossils, represented mainly by imprints or secondary external molds. A very limited number of taxa only possesses features which are indicative for their eumetazoan affinities. Thus, Vendoconularia triradiata had an inverted pyramidal theca covered with a complex sculpture alike that of some Cnidaria, (Scyphozoa?). Kimberella quadrata had a complicated non-metameric bilateral body, which left a wide variety of trace fossils of its intense locomotion, and, probably, could belong to the Trochozoa. Although morphological features of Keretsa brutoni were mostly lost during fossilization, it preserved an array of characteristics similar to those of arthropods, including antenna-like appendages, but lacking distinct trunk limbs and, probably, bilateral symmetry.

How to cite this article: Ivantsov A.Yu. 2017. The most probable Eumetazoa among late Precambrian macrofossils // Invert. Zool. Vol.14. No.2. P.127-133. doi: 10.15298/ invertzool.14.2.05

KEY WORDS: Late Precambrian, Eumetazoa, Bilateria, Vendoconularia, Kimberella, Keretsa.

\section{Наиболее вероятные остатки Eumetazoa среди макроископаемых позднего докембрия}

\section{А.Ю. Иванцов}

Палеонтологический институт им. А.А. Борисяка РАН, Профсоюзная ул., 123, Москва, 117647, Росcuя.E-mail: ivancov@paleo.ru

РЕЗЮМЕ: В комплексе позднедокембрийских макроископаемых, относящихся к мелководному морскому бентосу, различными исследователями идентифицируются остатки колониальных бактерий, многоклеточных водорослей, гигантских Protozoa, Parazoa, а также Eumetazoa нескольких типов. Однако достоверность этих определений невелика в силу ограничений, накладываемых особенностями сохранения докембрийского ископаемого материала, представленного в основном отпечатками или вторичными слепками поверхности тела. Принадлежность к Eumetazoa достаточно надежно устанавливается для очень ограниченного числа таксонов. Из Radiata это Vendoconularia triradiata (Cnidaria, Scyphozoa?), у которой выявлено наличие теки, имеющей форму конического бокала со сложно скульптированной 
наружной поверхностью. Из Bilateria это Kimberella quadrata (Trochozoa?), имевшая сложное по морфологии неметамерное тело и оставившая разнообразные следы своей интенсивной двигательной активности. Пример недостаточности утерянных при фоссилизации морфологических признаков для уверенной интерпретации ископаемых остатков являет Keretsa brutoni: у этого ископаемого есть черты членистоногих, в том числе структуры, похожие на антенны, но нет явных туловищных придатков и, возможно, настоящей билатеральной симметрии.

Как цитировать эту статью: Ivantsov A.Yu. 2017. The most probable Eumetazoa among late Precambrian macrofossils // Invert. Zool. Vol.14. No.2. P.127-133. doi: 10.15298/ invertzool.14.2.05

КЛЮЧЕВЫЕ СЛОВА: поздний докембрий, Eumetazoa, Radiata, Bilateria, Vendoconularia, Kimberella, Keretsa.

\section{Introduction}

Dozens of ihnofossils and "body" macrofossils have been found and described from upper Precambrian strata, which were thought to be barren (Fedonkin et al., 2007). However, the nature of these fossils is difficult to establish, and it is the subject of endless discussions. Difficulties of interpretation can be primarily explained by the nature of preservation of the Precambrian macrofossils, which are imprints and secondary external molds sometimes preserving selected areas of the surface only. These imprints and molds had undergone bacterial decomposition by the time of fixation in the rock. At the same time, only a single surface is usually preserved, either the upper or the lower one, in the bodies buried in situ, and cavities filled with sediment are preserved in a case of post-mortem transportation. The preservation of the bodies as imprints conceals any obvious physical and biochemical peculiarities of the primary biological material of these fossils. In fact it is hardly possible to perform histological and precise anatomical studies on such specimens, and the presence of even principal internal structures is commonly established on the basis of indirect evidences. However, for example, unapparent signs of the digestive system on imprints do not directly prove its primary absence in the organisms under study. The assemblages of benthic Precambrian macroorganisms (with a length of $=1 \mathrm{~cm}$ ) inhabiting the shallow sea in the Ediacaran or the late Vendian, about
560-545 million years ago, are the most well studied to date. Many of the late Precambrian macrofossils are comparable to fossils of Phanerozoic multicellular algae and animals by the level of morphological complexity. Some of them resembles in appearance modern representatives of various metazoan phyla. However, this resemblance is superficial, and there are a number of features in these fossils which either contradict or even prevent such direct comparisons under a closer examination. A great hope rests on biomarkers which can be extracted from rare indigenous organic matter of Precambrian macroorganisms. Thus, an additional evidence of Beltanelliformis affinities to cyanobacterial colonies was obtained by its biomarker studies (Bobrovskiy et al., 2016).

\section{Precambrian Eumetazoa}

Nowadays, remains of colonial bacterians, multicellular algae, giant protists, parazoans, and eumetazoans are identified among Precambrian macrofossils. We can not exclude the presence of representatives of some other groups among them as well (Seilacher, 1992). They may not be completely extinct, but are represented only by unicellular organisms in the modern biota. Among the possible animal remains only a few genera can be attributed to the Eumetazoa with sure due to peculiarities of preservation. The criteria for such an identification are as follows: (1) the presence of a thickened goblet-like external structure, the theca, 

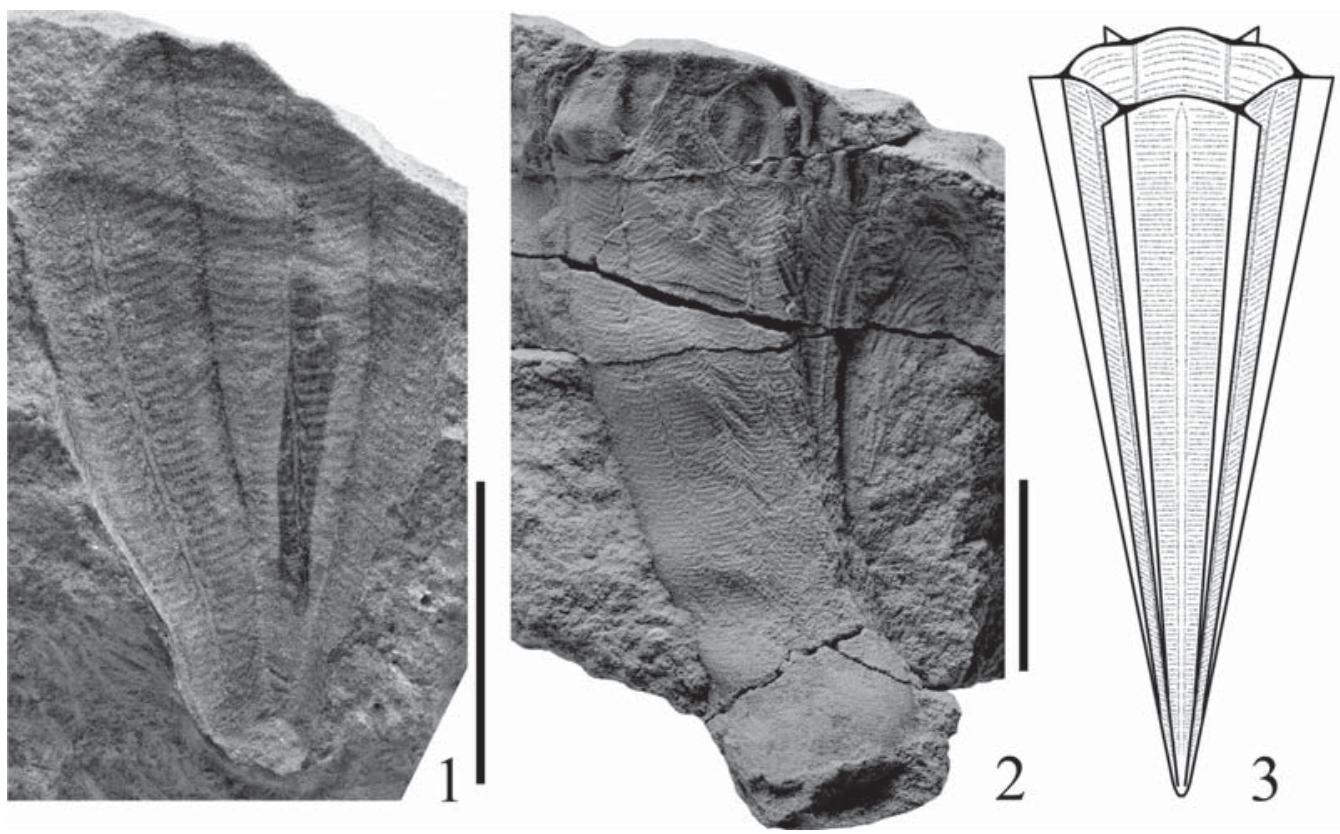

Fig. 1. Theca of Vendoconularia triradiata Ivantsov et Fedonkin, 2002. 1 - external surface imprint, holotype PIN, No. 4564/1025; 2 - natural imprint, specimen PIN, No. 4564/1045; 3 - reconstruction of the theca. Scale $1 \mathrm{~cm}$.

Рис. 1. Тека Vendoconularia triradiata Ivantsov et Fedonkin, 2002. 1 - отпечаток внешней поверхности, голотип ПИН, № 4564/1025; 2 — естественный слепок, экз. ПИН, № 4564/1045; 3 — реконструкция теки. Масштаб 1 см.

for radially symmetrical sedentary forms (Vendoconularia); (2) the apparent bilateral symmetry of the body and, at the same time, trace fossils of intense locomotion for the same unattached forms (Kimberella). Keretsa brutoni represents an example of the insufficiency of morphological features reduced during fossilization for its confident interpretation. Keretsa shows similarities with arthropods, including antennalike appendages, but lacks distinct trunk limbs and, probably, genuine bilateral symmetry.

Fossil remains of the Radiata (Vendoconularia triradiata Ivantsov et Fedonkin, 2002) represent the casts of the six-lobed inverted pyramids of a centimeter size closed at the point end (Fig. 1). The surface of each lobe bears 2 rows of dense transverse ridges scalloped along the outer edge. On the one hand, Vendoconularia resembles very much Paleozoic conulariids by principal morphological features. On the other hand, it is close to mostly early Cambrian anabaritids assigned to the Cnidaria (Scyphozoa)(Ivantsov, Zakrevskaya, 2017). Vendoconularia differs by the lack of any traces of primary mineralization, whereas conulariid thecae consist of phosphate, and anabaritid shells - of calcium carbonate. This feature of the majority of Vendian macrofossils can be explained by a number of reasons, from the non-ability of these organisms to biomineralize to the impossibility to distinguish manifestations of slight mineralization in siliciclastic deposits where these fossils have been buried.

Kimberella quadrata (Glaessner, Wade, 1966), representing the Bilateria, has a complex body with pronounced bilateral symmetry (Fig. 2). The abundance of fossils allows us to reconstruct it with an exceptional precision for Precambrian organisms (Ivantsov, 2010). Two parts are distinguished: a large trunk and a relatively small head, capable of being inverted into the trunk. The dorsal protective covers, armored 

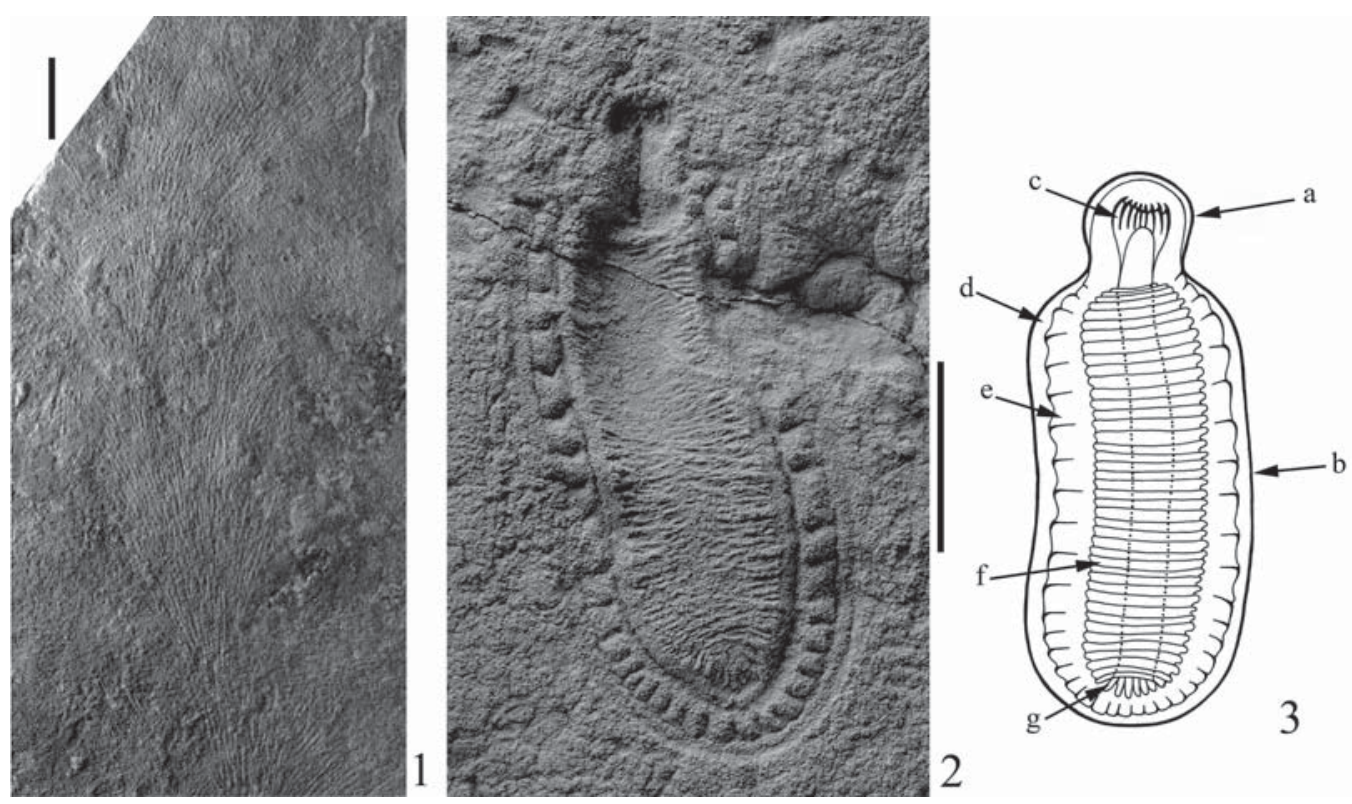

Fig. 2. Kimberella quadrata (Glaessner et Wade, 1966). 1 - feeding trace fossils, specimen PIN, No. 4853/ $313 ; 2$ - imprint of the dorsal body surface with marks the sclerites dissolved during fossilization, specimen PIN, No. 3993/9200; 3 - elements of the body structure visible on the imprint. Abbreviations: a - head; $\mathrm{b}$ - trunk; $\mathrm{c}$ - teeth; $\mathrm{d}$ - outer margin of the foot; $\mathrm{e}$ - scalloped margin of the dorsal covering; $\mathrm{f}$ transverse muscular bands; $\mathrm{g}$ - longitudinal muscular bands. Scale $1 \mathrm{~cm}$.

Рис. 2. Kimberella quadrata (Glaessner et Wade, 1966). 1 - следы питания, экз. ПИН, № 4853/313; 2 - отпечаток спинной стороны тела с растворенными в ходе фоссилизации склеритами спинных покровов, экз. ПИН, № 3993/9200; 3 — элементы строения, установленные по отпечатку. Обозначения: a - голова; $\mathrm{b}$ - туловище; c — зубы; d - внешний край ноги; $\mathrm{e}$ - фестончатый край спинных покровов; f - поперечные мускульные тяжи; g — продольные мускульные тяжи. Масштаб 1 см.

with fine sclerites, apparently mineral, but rapidly dissolving after burial, and a wide flat locomotor apparatus similar to the mollusk foot, are visible on the imprints. The central part of the body is occupied by a system of muscular bands stretched in the transverse and longitudinal directions. A bunch of deep furrows, sometimes visible in the head region, is interpreted as an imprint of a set of simple teeth. Despite the abundance of common morphological elements (marginal scallops of the dorsal cover, transverse muscular bands), there are no signs of a body metamery in Kimberella. Unique complicated imprints allow us to associate the body remains to certain feeding traces, namely, Kimberichnus teruzzii. The study of the morphology of body and trace fossils makes it possible to reconstruct the feeding behavior of this animal in details. By stretching and contracting its body, Kimberella was able to pull and push its head part bearing teeth in order to scratch the substrate covered by microbial mats on which it, probably, fed. It is possible that Kimberella was a facultative predator. Judging by a set of these features, this Precambrian organism belonged to the Trochozoa and, probably, was close to the ancestors of mollusks.

The first discovery of Keretsa brutoni was made by the author on the Winter Coast of the White Sea in the Zimnie Gory Formation in 2005 (Ivantsov, 2006a, b). The radiometric dating of the base of the formation is $555 \mathrm{Ma}$ (Martin et al., 2000). The imprint closely resembles an arthropod carapace by the presence of two sections, their general outlines and proportions, and by the presence of a longitudinal swell 

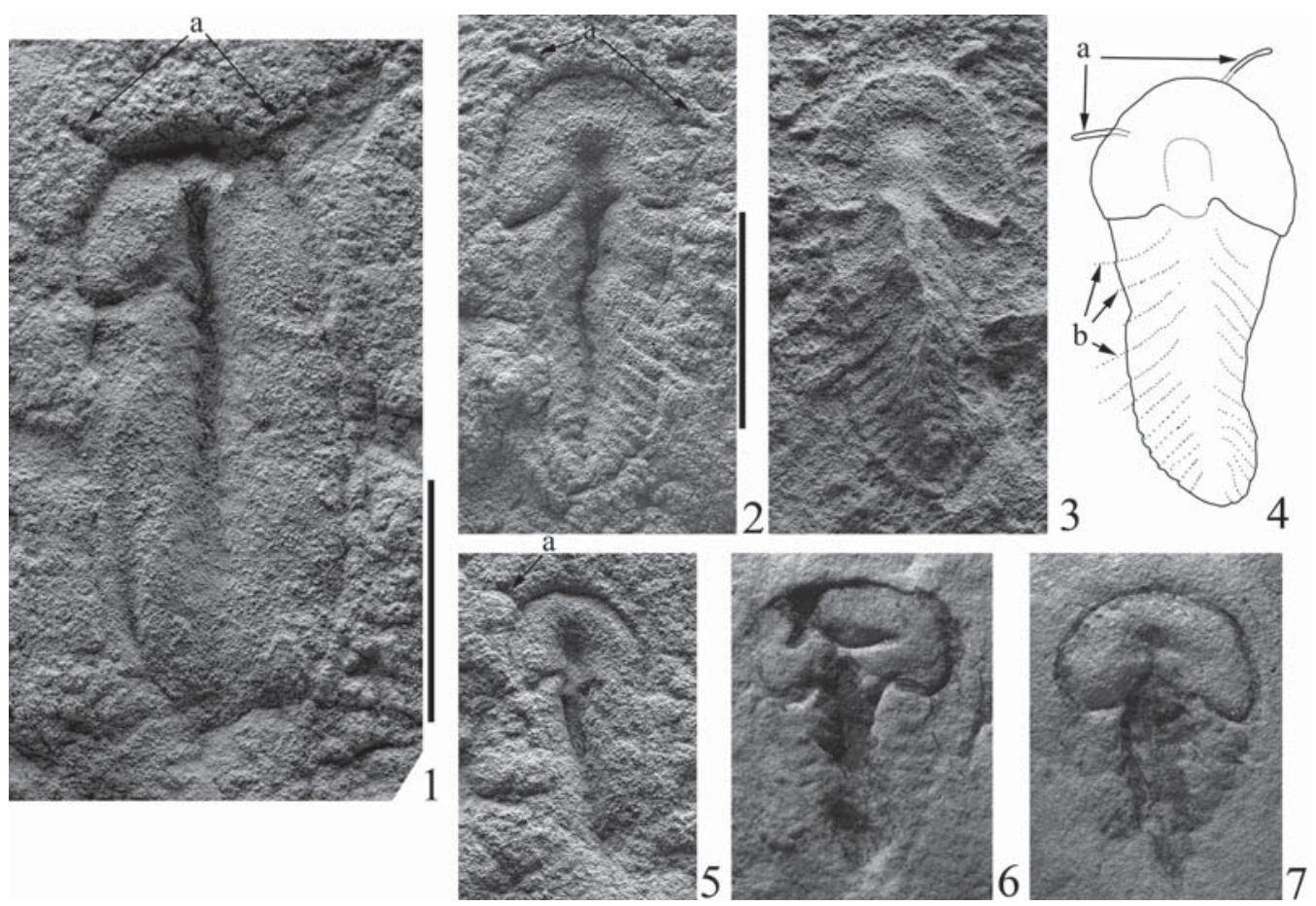

Fig. 3. Keretsa brutoni gen. et sp.n. 1 - holotype PIN, No. 3993/6390; 2-4 - specimen PIN, No. 3993/ 6660: 2 - imprint; 3 - latex cast; 4 — sketch of the cast; 5 - specimen PIN, No. 3993/6662; 6 - specimen PIN, No. 3993/8404; 7 - specimen PIN, No. 3993/8473. Abbreviations: a - possible impressions of the lateral appendages, antennae; $\mathrm{b}$ - possible impressions of the lateral appendages, trunk limbs. Scale $1 \mathrm{~cm}$. Рис. 3. Keretsa brutoni gen. et sp.n. 1 - голотип, ПИН, № 3993/6390; 2-4 - экз. ПИН, № 3993/6660: 2 - естественный отпечаток; 3 - латексный слепок; 4 - схематическая интерпретационная прорисовка по слепку; 5 - экз. ПИН, № 3993/6662; 6 - экз. ПИН, № 3993/8404; 7 - экз. ПИН, № 3993/8473. Обозначения: a - возможные отпечатки боковых придатков — антенн; $b$ - возможные отпечатки боковых придатков - туловищных конечностей. Масштаб 1 см.

(Fig. 3.1). Long narrow processes directed forward and sideward, which are detected in front of its smaller (head) section, are comparable to simple arthropod antennae. Oblique grooves that can be taken for the traces of trunk limbs are poorly visible within the larger (trunk) section.

Trilobite-like arthropods from the early $\mathrm{Pa}$ leozoic order Nektaspida display features which are very similar to those of Keretsa in both the morphology and the nature of preservation (Babcock, Chang, 1997). Due to a sensational character of such an interpretation, a publication of the fossil description was postponed until a new possibly more informative material would be discovered. During the following years, 10 more specimens were found in two burials on the Winter Coast, but they did not bring any conclu- sive evidence of its affinities to arthropods. Only 3 imprints revealed grooves possibly left by the antennae while transverse oblique-oriented structures are present on all the imprints (Fig. 3.1-3.5). However, these transverse structures are so distinct in one specimen that its trunk section looks to be segmented (Fig. 3.23.4). The pleural parts of arthropod segments can be preserved by a similar way, in a form of echelons with a sharp posterior margin. In the same time the isomers ("half-segments") of the Proarticulata, a well-known group of Vendian macroorganisms, also look similarly. The Proarticulata resemble arthropods, but completely lack any appendages. Besides, unlike the arthropod segments, the isomers of the Proarticulata are arranged in an alternate order along the 
longitudinal body axis. Their overall symmetry is not bilateral, but approaching the spiral-biradial one. This type of symmetry is not typical for the Metazoa, that is why, despite the presence of feeding and locomotion trace fossils, indicating a holozoan-type feeding and intense locomotion activity of the Proarticulata representatives, we can not be completely sure of their affinities to Eumetazoa. The trunk axial part of Keretsa specimen is wrinkled, and we can not prove either an opposite or an alternate (as in the Proarticulata) arrangement of the half-segments. At the same time, the echelon, which marked the posterior margin of the transverse element, is sometimes traced beyond the imprints on the adjacent matrix (Fig. 3.3-3.4). It is possible that we still observe some elements of the trunk limbs (for example, the edges of the gill paddles - the exopods of the trilobite-type limbs), more clearly expressed on the soft trunk bend above them, and less visible on the rock.

A systematic description of this fossil is first published in the appendix to this article (see below).

\section{Conclusion}

A great uniqueness of the organisms under discussion and the apparent absence of any common morphological features between them make it possible to date the time of the Eumetazoa divergence as the early Vendian or an even earlier part of Precambrian.

\section{Systematic description}

\section{Keretsa brutoni Ivantsov gen. et sp.n.}

Name: The genus is named after the Keretsa River; the species is named in honor of the
Norwegian paleontologist, Professor David L. Bruton.

Holotype. The specimen PIN No. 3993/ 6390; Arkhangelsk region, the Winter Coast of the White Sea, the Zimnie Gory, about $2 \mathrm{~km}$ to the north from the mouth of the Erga River; late Vendian, Zimnie Gory Formation, fossil assemblage Z11 (XXII).

Description. The body is soft, elongatedoval, flattened, and divided into two sections: a short, presumably head section and a longer trunk one. The maximum width of both sections is almost equal. A suture between the sections is distinct and looks like a simple furrow. The marginal edge of the body is even. A narrow swell resembling a trilobite rachis extends along the longitudinal axis of both sections. Straight or arcuate grooves are visible at the anterior edge of several specimens. These grooves are interpreted as the remains of a pair of anterior processes (antennae?), running under the head margin and protruding far beyond its limits. Pleurae of the trunk section either bear indistinct oblique hatching or are covered with sharp stepped folds. These structures can represent the traces of ventral limbs, which are «visible» through the body flattened against the sediment.

Dimensions in mm (see Table 1).

Comparison. Judging by the overall morphology and section proportions, the fossil resembles much fossil arthropods of the Naraoidae family, namely Naraoia longicaudata Zhang et Hou, 1985 from the early Cambrian of South China (Zhang, Hou, 1985); although Keretsa is certainly inferior in the completeness of the preservation. In some specimens of $N$. longicaudata, articulated shields only are preserved of its carapace, and the limbs are absent (Babcock, Chang, 1997). In places, the presence of the limbs is evident only as the weak

Table 1. Keretsa brutoni Ivantsov gen. et sp.n. The sizes of specimens of a type series (mm). Таблица 1. Keretsa brutoni Ivantsov gen. et sp.n. Размеры экземпляров типовой серии (мм).

\begin{tabular}{|l|c|c|c|}
\hline Collection nos. & Total body length & Maximum width & Length of head section \\
\hline $3993 / 6390$ holotype & 24.5 & 11 & 7.5 \\
\hline $3993 / 6660$ & 20 & 9.5 & 7 \\
\hline $3993 / 6662$ & 11.8 & 5.5 & 4.5 \\
\hline
\end{tabular}


folding and hatching on the dorsal surface of the trunk shield, similar to the one observed in Keretsa. However, the rachis of Naraoia never projects as prominently as in Keretsa.

Material and locality. 11 specimens from two fossil assemblages, Z1 (I) and Z11 (XXII), in the upper Vendian Erga and Zimnie Gory formations of the Zimnie Gory locality.

\section{Acknowledgements}

The work was supported by the RFBR grant No. 17-05-02212-a.

\section{References}

Babcock L.E., Chang W. 1997. Comparative taphonomy of two non-mineralized arthropods: Naraoia (Nektaspida; Early Cambrian, Chengjiang Biota, China) and Limulus (Xiphosurida; Holocene, Atlantic Ocean) // J. Chen, Y.N. Cheng, H.V. Iten (eds.). The Cambrian Explosion and the Fossil Record. Bulletin of the National Museum of Natural Science. No.10. P.233250 .

Bobrovskiy I., Hope J.M., Liyanage T.M., Brocks J.J. 2016. Biomarkers from the Ediacaran macrofossil Beltanelliformis // 19th Australian Organic Geochemistry Conference. 4-7 December 2016. Fremantle (Australia). P.50-51.

Fedonkin M.A., Gehling J.G., Grey K., Narbonne G., Vickers-Rich P., Clarke A.C. 2007. The Rise of Animals: Evolution and Diversification of the Kingdom Animalia. Baltimore: Johns Hopkins Univ. Press. $326 \mathrm{p}$.
Ivantsov A.Yu. 2006a. [On the finding of an arthropod animal of the Cambrian appearance in the Vendian of the Arkhangelsk region] // Sovremennaya paleontologiya: klassicheskaya i netradicionnaya. Materialy LII sessii Paleontologicheskogo obshchestva pri RAN. Sankt-Peterburg. P.58 [in Russian].

Ivantsov A.Yu. 2006b. New find of Cambrian type Arthropoda from the Ediacaran of the White Sea, Russia // Ancient Life and Modern Approaches. Abstracts of the Second International Palaeontological Congress. Beijing, China. P.280-281.

Ivantsov A.Yu. 2010. Paleontological evidence for the supposed Precambrian evolution of mollusks // Paleontological Journal. Vol.44. No.12. P.1552-1559.

Ivantsov A.Yu., Zakrevskaya M.A. 2017. [Precambrian Conularia-like fossils] // Paleostrat-2017. Godichnoe sobranie (nauchnaya konferentsiya) sektsii paleontologii MOIP i Moskovskogo otdeleniya Paleontologicheskogo obshchestva pri RAN. Tezisy dokladov. Moscow. P.28-29 [in Russian].

Martin M.W., Grazhdankin D.V., Bowring S.A., Evans D.A.D., Fedonkin M.A., Kirschvink J.L. 2000. Age of Neoproterozoic bilatarian body and trace fossils, White Sea, Russia: Implications for metazoan evolution // Science. Vol.288. P.841-845.

Seilacher A. 1992. Vendobionta and Psammocorallia: lost constructions of Precambrian evolution // Journal of the Geological Society. London. Vol.149. P.607-613.

Zhang W.T., Hou X.G. 1985. Preliminary notes on the occurrence of the unusual trilobite Naraoia in Asia // Acta Paleontologica Sinica. Vol.24. No.6. P.591595.

Responsible editor E.N. Temereva 